will have the support not merely of the peoples of both sides, but of the species Man".

\section{Humane Killing of Animals}

The Universities Federation for Animal Welfare has issued a revised edition of its pamphlet, "Kind Killing", dealing with the humane killing of animals (pp. 28 ; from the Federation, London, 1955 ; 6d.). The booklet is particularly valuable because the author, Dr. Jean Vinter, realizes that in many circumstances the methods advocated may not be practicable. Sodium pento-barbitone, for example, is recommended for killing dogs and cats, but the most humane ways of shooting these animals are also described. Where this cannot be done, the best way of chloroforming is explained, as are the methods to be used in gas poisoning and electrocution. A separate note is included on the disposal of new-born kittens and puppies. Besides mammals, the pamphlet gives some useful hints on the killing of birds, reptiles, amphibians, fish and invertebrates which are nuisances or needed for dissection.

\section{5 "Science in Industry" Essay Competition}

SEVENTY-SEVEN entries were received for the 1955 "Science in Industry" Essay Competition organized by the Sunday Times and Research. The Sunday Times section of the competition proved to be the more popular, forty-three entries being received for it. The entries were remarkable for their diffuseness, and none was written in a style suitable for a newspaper appealing to the lay public. In consequence, no award was made. The standard of the Research section of the competition was a little higher. The first prize ( $£ 100$ ) and the Waverley Gold Medal were awarded to Dr. F. Peter Woodford for an essay entitled "Living Reagents"; Dr. Woodford, Inter. national Wool Secretariat Postdoctoral Fellow in the University of Leeds, also received the special prize (£50) for the best entry from a competitor less than thirty years of age. The second prize was awarded to Dr. E. C. Potter, a physical chemist employed by the Central Electricity Authority, for an essay entitled "Corrosion in the Modern Power Station". Dr. Potter's essay will be published in Research.

\section{University of Birmingham}

THE following have been appointed to chairs in the University of Birmingham : Dr. D. G. Tucker, formerly senior principal scientific officer at H.M. Underwater Detection Establishment, Portland, to the chair of electrical engineering; and Prof. D. G. Catcheside, professor of genetics in the University of Adelaide (see Nature, 168, 234; 1951), to a chair of microbiology. The title of reader in chemical engineering has been conferred by the University on Dr. S. R. M. Ellis, and that of reader in pathology on Dr. D. B. Brewer. The following have been appointed lecturers: Dr. G. E. Brown (mathematical physics), Dr. G. Bullock (physical metallurgy), Dr. R. F. King (geophysics), J. Manhajm (mechanical engineering), Dr. W. T. W. Potts (zoology) and Dr. S. J. Taylor (mathematics). The following have been appointed to research fellowships: T. R. Carson (electron physics), B. W. Downs (mathematical physics), J. Graham (physical metallurgy), Dr. W. H. Holden (National Coal Board fellowship in chemistry), K. B. Mathur (Imperial Chemical Industries, Ltd., fellowship in chemical engineering), D. S. Rowe (experimental pathology), and Dr. W. I. Stephen (Imperial Chemical Industries, Ltd., fellowship in chemistry).

\section{University of Leeds}

THE University of Leeds has conferred the title of reader in textile industries on Dr. H. N. Chamberlain, senior lecturer in rayon technology in the Department of Textile Industries. The following have been appointed lecturers in the University : Dr. D. A. Armstrong (Brotherton research lecturer in physical chemistry); Dr. P. Gray (physical chemistry); Dr. B. W. Langley (organic chemistry); R. D. Mackey (civil engineering); and Dr. R. M. Tennent (physics).

\section{University of London}

THe following appointments have been made in the University of London: C. H. Barnett, senior lecturer at St. Thomas's Hospital Medical School, to the University readership in anatomy tenable at that School; and Dr. R. S. F. Schilling, reader in the Nuffield Department of Occupational Health in the University of Manchester, to the University readership in occupational health tenable at the London School of Hygiene and Tropical Medicine.

\section{Announcements}

SIR GEORGE BARNES, director of television, B.B.C., since 1950, has been appointed principal of the University College of North Staffordshire, Keele.

Sir Hrrbert Manzoni, engineer and surveyor of the City of Birmingham, has been elected chairman of the General Council of the British Standards Institution in succession to Mr. John Ryan, who has completed his three-year period of service as chairman. Sir Roger Duncalfe, chairman of British Glues and Chemicals, Ltd., has been re-elected president of the Institution, and Sir Stanley Rawson, vicechairman of John Brown and Co., Ltd., has been elected chairman of the Institution's Engineering Divisional Council.

THe following new appointments at the Brooklyn Botanic Garden, New York, have been announced : Dr. Walter R. Tulecke, formerly of Arizona State College, research associate; Miss Gunny Larsson, of the Arctic Horticultural Research Station at Öjebyn, Sweden, for one year as Ellen Eddy Shaw Fellow; Miss Charlotte Mentges, of Frankfurt, Germany, to the educational staff.

Prof. JoHN Wotiz, assistant professor of chemistry, has been appointed associate professor, and Maak-Sang Tsao, instructor of chemistry, has been appointed assistant professor in the University of Pittsburgh.

Sir Bernard KeEn, recently director of the East African Agriculture and Forestry Research Organization, has been appointed scientific advisor to Baird and Tatlock (London), Ltd., 14-17 St. Cross Street, London, E.C.1.

Messrs. Griffin and George, manufacturers of scientific apparatus, announce that, as from November 7 , the Griffin and Tatlock Division at Kemble Street, Kingsway, London, will be closed: all correspondence should be addressed to Griffin and George, Itd., Ealing Road, Alperton, Wembley, Middlesex (Tel.: PERivale 3344. Telegrams: Grifgeorge, Wembley).

ERRATum. In the communication entitled "Site of Virus-like Particles in Rous Fowl Sarcoma Cells", by M. A. Epstein, in Nature of October 22 , on p. 785 , col. 2, line 3, the word 'are' should be omitted; it is the vacuoles which are visible by phase-contrast microscopy. 